\title{
Ascendancy of Organic Based Nutrients for Boosting Rearing Performance of Silkworm (Bombyx mori L.)
}

\author{
Somagaini Pavankumar ${ }^{1 *}$, Kamlesh Bali ${ }^{1}$ and Suraksha Chanotra ${ }^{2}$ \\ ${ }^{1}$ Division of Sericulture, Agricultural Sciences and Technology of Jammu, \\ Chatha (India)- 180009, India \\ ${ }^{2}$ P.G. Department of Sericulture, Poonch Campus, University of Jammu, \\ Jammu \& Kashmir (India)-185101 \\ *Corresponding author
}

\begin{abstract}
A B S T R A C T
Nutrition plays a vital role in sericulture. It improves the quality of mulberry foliage and influences not only the growth and development of silkworm but also the quality and quantity of silk produced. Application of the required nutrient in the required amount to mulberry plant is, therefore, very essential for the successful silkworm growth and cocoon production. The present study was undertaken to work out the effect of organic manures (Vermicompost, farm yard manure-FYM, Silkworm rearing waste, Neem cake) alone and in combination with biofertilizer (Azospirillum) on mulberry (var. China white) and its impact was studied on rearing performance of silkworm hybrid $\left(\mathrm{FC}_{1} \times \mathrm{FC}_{2}\right)$. Larval growth, Cocoon and post cocoon parameters were significantly more when silkworm larvae fed on leaves from mulberry plant raised through the application of Vermicompost @ 4kg/plant + Azospirillum (4.0g/plant). Further FYM@4kg/plant + Azospirillum (4.0g/plant) found next best with respect to economic traits of silkworm. Consequently the present experiment revealed that Vermicompost @ 4kg/plant + Azospirillum (4.0g/plant) are responsible to produce good quality mulberry leaves and also for bring into being enriched yield with high quality of silk filament. Thus, application of Vermicompost + Azospirillum (T6) could form a suitable organic manure and biofertilizer combination from overall sericultural point of view.
\end{abstract}

\section{Introduction}

The discovery of silk or culturing of silkworms to produce silk, dates back to around $2700 \mathrm{BC}$, although archeological records point to silk production as early as yangshao period (5000-3000 BC) (Barber, 1992). Silk, is the most exquisite of all the textile fibres. Silk which is known for its richness, softness and flamboyance, is bright in color, soft in touch and elegant in look. Mulberry leaf is the sole source of food for silkworm (Bombyx mori L.) providing more than 70 per cent of material to biosynthesize silk proteins, sericin and fibroin. Being a monophagous insect, it derives almost all the nutrients essential for its growth from the mulberry leaf itself. Bulk of the silk produced 
in the world by the mulberry silkworm is directly derived from protein of mulberry leaves hence; silkworm should be feed with good quality of mulberry leaves in abundant quantity for the successful cocoon production. Good quality leaf production in mulberry is highly dependent on the supply of various inputs especially nitrogen and phosphorus fertilizers (Narseen et al., 1999). Application of organic fertilizers to mulberry had a significant influence on cocoon yield, shell ratio, silk productivity and single cocoon filament length (Sannappa et al., 2005). Nutrition plays an important role in improving the growth and development of the silkworm like other organisms. Silk production is dependent on the larval nutrition and nutritive value of mulberry leaves and plays a very effective role in producing good quality cocoon. There are various factors that reflect upon the successful cocoon crop production in sericulture such as mulberry leaf $(38.2 \%)$, climate $(37.0 \%)$, silkworm breed $(4.2 \%)$, rearing techniques $(9.3 \%)$, silkworm seed (3.1\%) and other factors (8.2\%) (Miyashita, 1986). Thus the mulberry leaf quality plays a predominant role in healthy growth of silkworms and the economic traits such as larval weight, cocoon weight and grainage parameters which are influenced largely by the nutritional status of the leaves fed to silkworm. The balanced nutritional status of the leaves enables the worms to mature early due to the faster metabolic activity (Sudhakara et al., 2017). The young age silkworm larvae usually prefer moisture rich, succulent and nutritive leaves, preferably the top ones which enable the young larvae to increase the amount of ingestion and digestion capacity thereby ensuring higher productivity (Yokoyama, 1974). Application of microbial inoculants in conjunction with organic manures has significantly increased the productivity of mulberry leaf (Rashmi et al., 2007).With this background the present study was undertaken to work out the effect of organic manures (Vermicompost, farm yard manure-FYM, Silkworm rearing waste, Neem cake) alone and in combination with Azospirillum on the production of quality mulberry foliage which in turn may exhibit significant bearing on growth and other cocoon traits of silkworm.

\section{Materials and Methods}

The present study was carried out at the Division of Sericulture, Sher-e-Kashmir University of Agricultural Sciences and Technology Jammu, Chatha, during 2018-19. Besides this, cocoon reeling parameters were conducted at Demonstration-Cum-Technical Service Centre, Central Silk Board, CSB Complex Miran Sahib, Jammu. In this experiment 2 years old plantation of mulberry (var. China white) trees were treated with organic manures alone and in combination with biofertilizer (Azospirillum) on the production of quality mulberry foliage which intern may exhibit significant bearing on growth and other cocoon traits of silkworm $\left(\mathrm{FC}_{1} \times \mathrm{FC}_{2}\right)$. The soil structure of the experimental farm is sandy clay loam with $\mathrm{pH}$ 7.12. The soil fertility of the experimental site was brought to homogeneous condition without applying any organic manures or fertilizers before raising mulberry crop for the present experiment. Seed of $\mathrm{FC}_{1} \times \mathrm{FC}_{2}$ was procured from RSRS, Dehradun and released from cold storage, incubated and reared during spring, 2019 in a Complete Random Block Design as per the standard rearing techniques of Krishanaswamy (1978). To know the effect of different organic manures on growth, yield and quality of mulberry in relation to rearing performances of silkworm, the following treatment combinations were used.

$\mathrm{T}_{1}: \quad$ FYM @ 4kg /plant

$\mathrm{T}_{2}$ : Vermicompost @ 4kg/plant

$\mathrm{T}_{3}$ : Silkworm Rearing Waste @ 3kg / plant 
$\mathrm{T}_{4}$ : Neem cake @ 2.5kg/plant

$\mathrm{T}_{5}$ : FYM @ 4kg /plant + Azospirillum (@ $4.0 \mathrm{~g}$ /plant)

$\mathrm{T}_{6}$ : Vermicompost @ 4kg /plant + Azospirillum (4.0g/plant)

$\mathrm{T}_{7}$ : Silkworm Rearing Waste @ 3kg /plant + Azospirillum (4.0g/plant)

$\mathrm{T}_{8}$ : Neem cake @ $2.5 \mathrm{~kg} / \mathrm{plant}+$ Azospirillum (4.0 g /plant)

$\mathrm{T}_{9}$ : Control (No manure/fertilizer application)

Mulberry leaves raised by application of the above treatments were fed to silkworm, Bombyx mori larvae $\left(\mathrm{FC}_{1} \times \mathrm{FC}_{2}\right)$ three times a day. The newly hatched silkworm larvae were divided into nine treatments including control. The rearing tray with 100 larvae fed with mulberry leaves grown without the application of manures/fertilizers served as control (standard). Each treatment represented by three replicates. Each replicates one hundred larvae. For each chopped leaves were offered three times daily to young silkworm (I, II \& III instars). While, whole leaves were offered for grown silkworm (IV and V instars). Bed cleaning was done according to recommended schedule (once during I-instar before first moult; twice during II-instar after first \& before second moults; thrice during III-instar after second moult, middle of third instar \& before third moult; and every day during IV \& V instars) (Dandin et al., 2003). As the larvae grew, the required spacing was appropriately provided. In order to control the incidence of diseases, Vijetha (recommended bed disinfectant) was dusted at the rate of 5.5 $\mathrm{kg} / 100$ disease free layings (dfls) after bed cleaning and 30 minutes before feeding resumes as per the recommendation given by Dandin et al., (2003). The following characters were Silkworm Growth Parameters (Total larval life duration (Days and Hours), Weight of 10 mature larvae (g), Larval survival percentage), Cocoon Characters (Cocoon yield/10000 larvae, Single cocoon weight (g), Single shell weight (g), Shell ratio percentage) and Post Cocoon Characters (Total Filament length, Non breakable filament length (m), Filament size (d), were studied and investigated.

\section{Statistical analysis}

All the data recorded during the course of experimentation was analyzed by using statistical package (SPSS 16.0). Effects of different treatments on mulberry, silkworm growth, and cocoon and post cocoon parameters were analyzed using one way ANOVA. Differences between means were tested by using Tukey's HSD $(\mathrm{P}<0.05)$

\section{Results and Discussion}

The results of the present study are tabulated in tables 1 to 3 and are interpreted in the light of earlier work are here under.

\section{Larval parameters}

Larval traits viz. weight of 10 mature larvae, larval survival per cent differed considerably when worms fed on mulberry grown by the application of varied sources of organic manures alone and in combination with biofertilizer (Azospirillum). The data presented in the Table 1 revealed that when worms were fed with mulberry grown through application of different organic manures alone and in combination with biofertilizer (Azospirillum), resulted in significantly higher weight of 10 mature larvae $(\mathrm{F}=16.463$; $\mathrm{df}=$ 8; $P=0.000)$ maximum being with the application of vermicompost + Azospirillum $\left(\mathrm{T}_{6}\right)(46.69 \pm 0.66)$ followed by $\mathrm{T}_{5}(44.22 \pm$ $0.90)$ which was found statistically at par with $\mathrm{T}_{8}(44.03 \pm 0.56)$ and $\mathrm{T}_{2}(43.13 \pm 0.49)$ whereas, significantly lower results were observed in control $\left(T_{9}\right)$ (37.66 \pm 0.33$)$. However, non significant differences were observed between $\mathrm{T}_{7}(42.66 \pm 0.33), \mathrm{T}_{1}(42.32$ 
$\pm 0.72), \mathrm{T}_{4}(42.00 \pm 0.58)$ and $\mathrm{T}_{3}(41.98 \pm$ $0.58)$. With respect to, larval survival per cent $(\mathrm{F}=14.615 ; \mathrm{df}=8 ; P=0.000)$, application of vermicompost + Azospirillum $\left(\mathrm{T}_{6}\right)$ resulted in significantly higher larval survival per cent $(97.05 \pm 0.58)$ followed by $\mathrm{T}_{5}(96.27 \pm 0.67)$ which was found statistically at par with $\mathrm{T}_{8}$ (95.74 \pm 0.43$), \mathrm{T}_{2}(94.97 \pm 1.06), \mathrm{T}_{7}(94.23 \pm$ $0.52)$ and $T_{1}(93.77 \pm 0.95)$ Whereas significantly lower larval survival per cent was registered in control $\left(\mathrm{T}_{9}\right)(88.04 \pm 0.58)$. However, non significant differences were observed between $\mathrm{T}_{4}(92.17 \pm 0.89)$ and $\mathrm{T}_{3}$ $(91.87 \pm 0.58)$.

\section{Cocoon parameters}

The data regarding cocoon parameters presented in Table 2 revealed that cocoon yield by weight in $\mathrm{kg}(\mathrm{F}=2368.000 ; \mathrm{df}=8 ; P$ $=0.000)$ through application of vermicompost + Azospirillum $\left(\mathrm{T}_{6}\right)$ exhibited better results $(14.26 \pm 0.01)$ followed by $\mathrm{T}_{5}(14.08 \pm 0.02)$ which was found statistically at par with $\mathrm{T}_{8}$ (14.01 \pm 0.01). While significantly lower cocoon yield by weight was registered in control $\left(\mathrm{T}_{9}\right)(12.03 \pm 0.01)$. However, non significant differences were observed between $\mathrm{T}_{3}(13.01 \pm 0.01)$ and $\mathrm{T}_{4}(13.09 \pm 0.01)$. Cocoon yield by number $(\mathrm{F}=1136.000 ; \mathrm{df}=$ $8 ; P=0.000)$, in respect of this parameter application of vermicompost + Azospirillum $\left(\mathrm{T}_{6}\right)$ exhibited better results $(8987 \pm 5.51)$ followed by $\mathrm{T}_{5}(8872 \pm 4.1)$ and $\mathrm{T}_{8}(8763 \pm$ 2.52). While significantly lower cocoon yield by number was registered in control $\left(\mathrm{T}_{9}\right)$ $(7847 \pm 2.89)$. Single cocoon weight $(\mathrm{F}=$ 74.302 ; df $=8 ; P=0.000)$, in respect of this parameter application of vermicompost + Azospirillum $\left(\mathrm{T}_{6}\right)$ exhibited better results $(2.06 \pm 0.01)$ followed by $\mathrm{T}_{5}(2.03 \pm 0.01)$ which was found statistically at par with $\mathrm{T}_{8}$ $(2.02 \pm 0.01)$. While significantly lowest single cocoon weight was registered in control $\left(\mathrm{T}_{9}\right)(1.80 \pm 0.01)$. However, non significant differences were observed between
$\mathrm{T}_{1}(1.97 \pm 0.01)$ and $\mathrm{T}_{4}(1.96 \pm 0.01)$. Single shell weight $(\mathrm{F}=38.893$; $\mathrm{df}=8 ; P=0.000)$, in respect of this parameter application of vermicompost + Azospirillum $\left(\mathrm{T}_{6}\right)$ exhibited better results $(0.48 \pm 0.00)$ followed by $\mathrm{T}_{5}$ $(0.46 \pm 0.01)$ and $\mathrm{T}_{8}(0.45 \pm 0.01)$ respectively over other treatments. While, significantly lower single shell weight was observed in control $\left(\mathrm{T}_{9}\right)(0.31 \pm 0.00)$. Shell ratio $(\mathrm{F}=$ 13.634; df $=8 ; P=0.000)$ in respect of this parameter application of vermicompost + Azospirillum $\left(\mathrm{T}_{6}\right)$ exhibited better results $(23.10 \pm 0.17)$ which was at par with $\mathrm{T}_{5}$ $(22.66 \pm 0.26)$ whereas it was significantly less in Control $\left(\mathrm{T}_{9}\right)(17.00 \pm 0.13)$. However, non significant differences were observed between $\mathrm{T}_{8}(22.24 \pm 0.57), \mathrm{T}_{2}(21.38 \pm 0.55)$, $\mathrm{T}_{7}(20.98 \pm 0.53)$ and $\mathrm{T}_{1}(20.31 \pm 0.33)$.

\section{Post cocoon parameters}

The data presented in the table 3 revealed that worms were fed with mulberry grown by the application of different organic manures alone and in combination with Azospirillum, exhibited significant results in respect of total filament length $(\mathrm{m})(\mathrm{F}=304.891 ; \mathrm{df}=8 ; \mathrm{p}=$ 0.000) with maximum being with the application of vermicompost + Azospirillum ( $\left.\mathrm{T}_{6}\right)(1308.00 \pm 9.07)$ which was at par with $\mathrm{T}_{5} \quad(1269.00 \pm 8.19)$ whereas it was significantly less in Control $\left(\mathrm{T}_{9}\right)(968.00 \pm$ 5.03). However, non significant differences were observed between $\mathrm{T}_{2}(1165.00 \pm 3.46)$, $\mathrm{T}_{7}(1163.00 \pm 4.73)$ and $\mathrm{T}_{1}(1141.00 \pm 3.21)$. Non-breakable filament length $(\mathrm{m}) \quad(\mathrm{F}=$ 1522.000; $\mathrm{df}=8 ; \mathrm{p}=0.000$ ), in respect of this parameter application of vermicompost + Azospirillum $\left(\mathrm{T}_{6}\right)$ exhibited better results $(1308.000 \pm 4.73)$ followed by $\mathrm{T}_{5}(1165.00 \pm$ $3.61)$ and $T_{8}(1141.00 \pm 5.13)$ respectively over other treatments. Whereas, significantly lower results was recorded in control $\left(\mathrm{T}_{9}\right)$ $(806.00 \pm 3.79)$. However, non significant differences were observed between $T_{2}$ $(1058.00 \pm 3.21)$ and $\mathrm{T}_{7}(1049.00 \pm 2.89)$. 
Filament size $(\mathrm{d})(\mathrm{F}=133.762 ; \mathrm{df}=8 ; \mathrm{p}=$ 0.00 ), in respect of this parameter application of vermicompost + Azospirillum $\left(\mathrm{T}_{6}\right)$ resulted in significantly finer denier $(2.50 \pm 0.02)$ followed by $\mathrm{T}_{5}(2.73 \pm 0.01)$ and $\mathrm{T}_{8}(2.79 \pm$ $0.01)$ respectively over other treatments. However, coarser denier was observed in
Control $\left(\mathrm{T}_{9}\right)(2.93 \pm 0.01)$. The importance of mulberry in sericulture industry can be realized from the fact that mulberry leaves form the only food material required by silkworm Bombyx mori L. (Chanotra et al., 2019).

Table.1 Larval traits of bivoltine silkworm hybrid $\left(\mathrm{FC}_{1} \times \mathrm{FC}_{2}\right)$ as influenced by different organic manures applied to mulberry

\begin{tabular}{|c|c|c|}
\hline Treatments & $\begin{array}{c}\text { Weight of 10 mature larvae } \\
(\mathbf{g})\end{array}$ & Larval Survival per cent \\
\hline $\mathbf{T}_{\mathbf{1}}$ & $42.32 \pm 0.72 \mathrm{~b}$ & $93.77 \pm 0.95 \mathrm{bc}$ \\
\hline $\mathbf{T}_{\mathbf{2}}$ & $43.13 \pm 0.49 \mathrm{bc}$ & $94.97 \pm 1.06 \mathrm{bc}$ \\
\hline $\mathbf{T}_{\mathbf{3}}$ & $41.98 \pm 0.58 \mathrm{~b}$ & $91.87 \pm 0.58 \mathrm{ab}$ \\
\hline $\mathbf{T}_{\mathbf{4}}$ & $42.00 \pm 0.58 \mathrm{~b}$ & $92.17 \pm 0.89 \mathrm{ab}$ \\
\hline $\mathbf{T}_{\mathbf{5}}$ & $44.22 \pm 0.90 \mathrm{bc}$ & $96.27 \pm 0.67 \mathrm{bc}$ \\
\hline $\mathbf{T}_{\mathbf{6}}$ & $46.69 \pm 0.66 \mathrm{c}$ & $97.05 \pm 0.58 \mathrm{c}$ \\
\hline $\mathbf{T}_{\mathbf{7}}$ & $42.66 \pm 0.33 \mathrm{~b}$ & $94.23 \pm 0.52 \mathrm{bc}$ \\
\hline $\mathbf{T}_{\mathbf{8}}$ & $44.03 \pm 0.56 \mathrm{bc}$ & $95.74 \pm 0.43 \mathrm{bc}$ \\
\hline $\mathbf{T}_{\mathbf{9}}$ & $37.66 \pm 0.33 \mathrm{a}$ & $88.04 \pm 0.58 \mathrm{a}$ \\
\hline
\end{tabular}

Values are Means $\pm \mathrm{SE}$

Means within a column followed by different letters are significantly different $\mathrm{P}<0.01$

Table. 2 Cocoon traits of bivoltine silkworm hybrid $\left(\mathrm{FC}_{1} \times \mathrm{FC}_{2}\right)$ as influenced by different organic manures applied to mulberry

\begin{tabular}{|c|c|c|c|c|c|}
\hline \multirow[t]{2}{*}{ Treatments } & \multicolumn{2}{|c|}{ Cocoon yield /10000 larvae } & \multirow{2}{*}{$\begin{array}{l}\text { Single Cocoon } \\
\text { Weight (g) }\end{array}$} & \multirow{2}{*}{$\begin{array}{c}\text { Single Shell } \\
\text { Weight (g) }\end{array}$} & \multirow[t]{2}{*}{ Shell ratio \% } \\
\hline & By wt. & By No. & & & \\
\hline $\mathbf{T}_{1}$ & $13.22 \pm 0.02 \mathrm{c}$ & $8483 \pm 4.04 \mathrm{~d}$ & $1.97 \pm 0.01 \mathrm{bc}$ & $0.40 \pm 0.01 \mathrm{bcd}$ & $20.31 \pm 0.33 b c$ \\
\hline $\mathbf{T}_{2}$ & $13.88 \pm 0.02 \mathrm{e}$ & $8649 \pm 2.31 \mathrm{f}$ & $2.00 \pm 0.01 \mathrm{~cd}$ & $0.43 \pm 0.01 \mathrm{cdef}$ & $21.38 \pm 0.55 b c$ \\
\hline $\mathbf{T}_{3}$ & $13.01 \pm 0.01 \mathrm{~b}$ & $8219 \pm 1.73 \mathrm{~b}$ & $1.93 \pm 0.01 \mathrm{~b}$ & $0.37 \pm 0.01 \mathrm{~b}$ & $19.57 \pm 0.72 a b$ \\
\hline $\mathbf{T}_{4}$ & $13.09 \pm 0.01 \mathrm{~b}$ & $8376 \pm 2.89 \mathrm{c}$ & $1.96 \pm 0.01 \mathrm{bc}$ & $0.39 \pm 0.01 \mathrm{bc}$ & $20.07 \pm 0.80 \mathrm{abc}$ \\
\hline $\mathbf{T}_{5}$ & $14.08 \pm 0.02 \mathrm{f}$ & $8872.7 \pm 4.1 \mathrm{~h}$ & $2.03 \pm 0.01 \mathrm{de}$ & $0.46 \pm 0.01$ ef & $22.66 \pm 0.26 \mathrm{c}$ \\
\hline $\mathbf{T}_{6}$ & $14.26 \pm 0.01 \mathrm{~g}$ & $8987 \pm 5.51 \mathrm{i}$ & $2.06 \pm 0.01 \mathrm{e}$ & $0.48 \pm 0.00 \mathrm{f}$ & $23.10 \pm 0.17 \mathrm{c}$ \\
\hline $\mathbf{T}_{7}$ & $13.41 \pm 0.01 \mathrm{~d}$ & $8592 \pm 1.73 \mathrm{e}$ & $1.99 \pm 0.01 \mathrm{~cd}$ & $0.42 \pm 0.01$ bcde & $20.98 \pm 0.53 \mathrm{bc}$ \\
\hline $\mathbf{T}_{8}$ & $14.01 \pm 0.01 \mathrm{f}$ & $8763 \pm 2.52 \mathrm{~g}$ & $2.02 \pm 0.01 \mathrm{de}$ & $0.45 \pm 0.01 \mathrm{def}$ & $22.24 \pm 0.57 b c$ \\
\hline $\mathbf{T}_{9}$ & $12.03 \pm 0.01 \mathrm{a}$ & $7847 \pm 2.89 \mathrm{a}$ & $1.80 \pm 0.01 \mathrm{a}$ & $0.31 \pm 0.00 \mathrm{a}$ & $17.00 \pm 0.13 \mathrm{a}$ \\
\hline
\end{tabular}

Values are Means \pm SE

Means within a column followed by different letters are significantly different $\mathrm{P}<0.01$ 
Table.3 Post Cocoon traits of bivoltine silkworm hybrid $\left(\mathrm{FC}_{1} \times \mathrm{FC}_{2}\right)$ as influenced by different organic manures applied to mulberry

\begin{tabular}{|c|c|c|c|}
\hline Treatments & Total filament length $(\mathbf{g})$ & $\begin{array}{c}\text { Non breakable filament length } \\
(\mathbf{m})\end{array}$ & $\begin{array}{c}\text { Filament size } \\
(\mathbf{d})\end{array}$ \\
\hline $\mathbf{T}_{\mathbf{1}}$ & $1141.00 \pm 3.21 \mathrm{c}$ & $1019.00 \pm 2.08 \mathrm{c}$ & $2.81 \pm 0.01 \mathrm{~cd}$ \\
\hline $\mathbf{T}_{\mathbf{2}}$ & $1165.00 \pm 3.46 \mathrm{c}$ & $1058.00 \pm 3.21 \mathrm{~d}$ & $2.86 \pm 0.01 \mathrm{def}$ \\
\hline $\mathbf{T}_{\mathbf{3}}$ & $1018.00 \pm 2.65 \mathrm{~b}$ & $971.00 \pm 1.73 \mathrm{~b}$ & $2.73 \pm 0.01 \mathrm{~b}$ \\
\hline $\mathbf{T}_{\mathbf{4}}$ & $1049.00 \pm 7.55 \mathrm{~b}$ & $1012.00 \pm 3.61 \mathrm{c}$ & $2.79 \pm 0.01 \mathrm{bc}$ \\
\hline $\mathbf{T}_{\mathbf{5}}$ & $1269.00 \pm 8.19 \mathrm{e}$ & $1165.00 \pm 3.61 \mathrm{f}$ & $2.90 \pm 0.02 \mathrm{f}$ \\
\hline $\mathbf{T}_{\mathbf{6}}$ & $1308.00 \pm 9.07 \mathrm{e}$ & $1308.00 \pm 4.73 \mathrm{~g}$ & $2.93 \pm 0.01 \mathrm{f}$ \\
\hline $\mathbf{T}_{\mathbf{7}}$ & $1163.00 \pm 4.73 \mathrm{c}$ & $1049.00 \pm 2.89 \mathrm{~d}$ & $2.83 \pm 0.01 \mathrm{cde}$ \\
\hline $\mathbf{T}_{\mathbf{8}}$ & $1215.00 \pm 10.07 \mathrm{~d}$ & $1141.00 \pm 5.13 \mathrm{e}$ & $2.89 \pm 0.01 \mathrm{ef}$ \\
\hline $\mathbf{T}_{\mathbf{9}}$ & $968.00 \pm 5.03 \mathrm{a}$ & $806.00 \pm 3.79 \mathrm{a}$ & $2.50 \pm 0.02 \mathrm{a}$ \\
\hline
\end{tabular}

Values are Means $\pm \mathrm{SE}$

Means within a column followed by different letters are significantly different $\mathrm{P}<0.01$

Production of high quality silk therefore demands the overall improvement of the host plant manifested in terms of qualitative and quantitative leaf production. Silkworm larvae fed with mulberry leaves raised with the application of vermicompost + Azospirilum $\left(\mathrm{T}_{6}\right)$ showed higher values for cocoon yield per 1000 larvae by number and by weight $(8987 \pm 5.51$ and $14.26 \pm 0.01 \mathrm{~kg}$ respectively), single cocoon weight $(\mathrm{g})(2.06 \pm 0.01)$, single shell weight $(\mathrm{g})(0.48 \pm 0.00)$ and shell ratio percentage $(23.10 \pm 0.17)$.

Significant increase was also observed for the same treatments in case of post cocoon matric traits including total filament length (m)

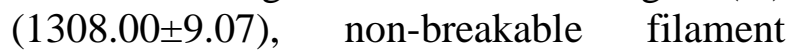
length $(\mathrm{m})(1308.00 \pm 4.73)$ and filament size (d) $(2.50 \pm 0.02)$. These results are in confirmation with the findings of Naika et al., (2011) and Venugopal et al., (2010) who recommended the application of vermicompost for better growth and yield in mulberry as well as in silkworm. Mahmood et al., (2002) reported the similar results when silkworm larvae were fed with mulberry leaves supplemented with FYM and different doses of NPK and Sori and Bhaskar (2012), reported increase in post cocoon characters by feeding the larvae on mulberry leaves grown in FYM treatment soil, suggesting the application of FYM in mulberry cultivation for obtaining higher yield and better post cocoon traits.

On the basis of current findings it may been concluded that, mulberry leaves treated with the application of vermicompost $(4.0 \mathrm{Kg})+$ Azospirillum (4.0 g/plant) supported better growth, Cocoon and post cocoon parameters of silkworm. This could be due to considerable research evidence that earthworms stimulate the microbial decomposition of organic matter significantly, thereby releasing the nutrients in available form to mulberry tree which has a direct effect on quality of mulberry leaves, which might have enhanced palatability and acceptability of leaves, increased feeding efficiency of silkworms and thereby resulting in good cocoon yield. Whereas, other organic manures like FYM, silkworm rearing waste and neem cake may require some more time to breakdown into simpler molecules and to release nutrients to the soil and making them available to mulberry tree for its utilization. Thus, application of vermicompost + Azospirillum $\left(\mathrm{T}_{6}\right)$ could form a suitable organic manure and biofertilizer combination from overall sericultural point of view. 


\section{References}

Barber, E. J. W. 1992. Prehistoric textiles: the development of cloth in the Neolithic and Bronze Ages with Special reference to the Aegean (reprint, illustrated Ed.). Published by Princeton University Press. P. 31.

Chanotra. S., Bali. R. K. and Bali. K. 2019 b. Morpho-physiological characterization of mulberry genotypes (Morus spp.) for inheritance in future breeding programme. Journal of Pharmacognosy and Phytochemistry. 8(1): 2695-2701.

Dandin, S. B., Jayaswal, J and Giridhar, K. 2003. Handbook of Sericulture Technologies, Central Silk Board, Bangalore, India, p. 259.

Krishnaswami, S. 1978. New technology of silkworm rearing. Indian silk, 16 (12): 7-15.

Miyashita, V., 1986, A report on mulberry cultivation and training methods suitable to bivoltine rearing in Karnataka, Central Silk Board, Bangalore, India.

Mohamood, R., Tahir jan, Md. and Idrees Khan, Md. 2002. Effect of nitrogen (farmyard manure + urea) treated mulberry trees on the larval development and cocoon weight of silkworm (Bombyx mori L.). Asian Journal of Plant Sciences, 1(2): 93-94.

Naika, R., Sannappa, B., Bhaskar, R.N. and Devaiah, M. C. 2011. Investigation on the Sources of organics for mulberry and its impact on quantitative traits of the silkworm. International Journal of Science and Nature, 2(1): 114-117.

Narseen, A., Cheena, G. M. and Ashfaq, M. 1999. Rearing of milk Bombyx Mori L. on alternative food parts. Pakistan. Journal of
Biological Sciences, 2: 843-845.

Rashmi, K., Shankar, M. A., Shashidhar, K. R. and Narayanaswamy, T. K. 2009. Growth and foliar constituents of mulberry (M5) cultivated under organic based nutrient management. International Journal of Industrial Entomology, 19 (1):165-169.

Sannappa, B., Naika, R., Govindan, R., Jagadeesh, K. T. S. and Venkataramana, G. V. 2005. Growth and yield traits of mulberry as influenced by different levels of vermicompost. In: Proceedings of National Seminar on Composting and Vermicomposting, CSR\&TI, Mysore, India, p. 166.

Sori, W. and Bhaskar, R. N. 2012. Effect of bioinoculants applied to M5 mulberry under rain-fed condition on growth and cocoon traits performance of silkworm (Bombyx mori L.). Momona Ethiopian Journal of Science, 4(2): 29-39.

Sudhakara, S. N. and Narayanaswami, T. K. 2017. Late age worm (Bombyx mori L.) rearing performance as influenced by feeding schedules of mulberry leaf raised through the concept of organic based nutrient management. International Journal of Current Research, 9(10): 58502-58505.

Venugopal, A., Chandrasekhar, M., Naidu, B. V. and Raju, S. 2010. Vermicomposting In Sericulture using Mixed Culture of Earthworms (Eudrillus eugineae, Eisenia foetida and Perionyx excavatus ) - A Review. Agricultural Reviews, 31(2): 150154.

Yokoyama, T. 1974. Text Book of Tropical Sericulture, pp. 444-537. Japan Overseas Cooperation Volunteers, Tokyo.

\section{How to cite this article:}

Somagaini Pavankumar, Kamlesh Bali and Suraksha Chanotra. 2020. Ascendancy of Organic Based Nutrients for Boosting Rearing Performance of Silkworm (Bombyx mori L.). Int.J.Curr.Microbiol.App.Sci. 9(07): 1665-1671. doi: https://doi.org/10.20546/ijcmas.2020.907.192 